\title{
コースラインの自動設定に関する研究
}

原潔*・田中 隆博**

\section{A Basic Study on Automatic Course Line Setting}

\author{
Kiyoshi HARA and Takahiro TANAKA
}

\begin{abstract}
If there were no traffic regulations on the water, a ship could go freely. So, she would have wide choice of routes and course lines on the way to the destination. And if we could set the course line automatically, and it were efficient and safe one, not merely it would lighten burden on the navigator, but aid her to avoid running ashore.

In this paper, the authors proposed the algorithm to set the tactical route and the strategic course line, and analyzed the navigator's Subjective risk Judgement for Land $\left(\mathrm{SJ}_{\mathrm{L}}\right)$ which based on experiments using maneuvering simulator. Moreover, the authors studied what $\mathrm{SJ}_{\mathrm{L}}$ level the navigator adopted on common navigation. Finally, some examples of the course line which based on the automatic setting procedure were indicated.
\end{abstract}

\section{1.はじめに}

船舶は、水深が自船の喫水を超える連続する水域を自由に航行できる。1.5次元的にしか行動できない自 動車や 3 次元で行動する定期航空機と比べても、船舶の進路の大部分は操船者の判断に委㸚られている。 一般的に、任意の 2 地点の間に設定し得るコースラインは無限に存在し、その中から適当なコースライン を設定するのは困難と考えられてきたためか、自動運航システムや交通流シミュレーションなどにおいて もコースラインは与件とされているか、自動設定と称しても戦術的レベルにとどまった議論しかされてい ない。

かりに、無限に設定し得るコースラインの中から、効率的かつ安全なものが自動的に設定でき、さらに コースラインについて定量的な評価ができれば、自船の乗揚げの防止や操船者の負担の軽減、をた、評価 指標と基準を共有することによるV T S などからの客観的な船舶の航行状態の評価を行うことができる。

そこで、本研究では、簡単なアルゴリズムを用い 2 次元情報からコースラインの自動選定を行う手法に ついて検討するとともに、実際の操船者の俈険度感覚を取り入れ、その有効性について検討した。

\section{2.コースライン選定のアルゴリズム}

\section{1 コースライン自動設定の概要}

図 1 に示すように、コースラインの自動設定法、「前処理」及び「計算機による処理」に分けられる。「前 処理」についても自動化することが望ましいが、機材の関係上省略することとした。よって、「スキャナ取 り込み」「ノイズ除去」「2 值画像化」については手作業で行い、今回は「計算機による処理」の部分の自 動化を試みた。

初期情報として 2 值画像、 $\mathrm{OD}$ 情報（起点と終点の座標）及び 1 画素あたりの長さの情報を用いた。 2

*正 会 員 神戸商船大学（勇658 神戸市東灘区媣江南町5-1-1）

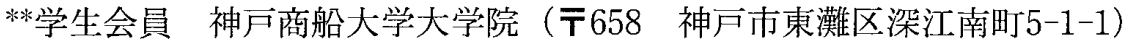


值画像は空間フィルタを用いることで簡単に特徵 点の抽出などが可能(1)であり、2 次元の地形情報を 獲得するのに有効である。

コースラインの設定は、戦略的航路選択、戦術 的航路選択及び整形フィルタの 3 段階で行った。 戦略的航路選択之は、画像処理によって得られた 陸岸情報から、ノードの位置を決定し、Dijkstra（ダ イクストラ)法(2)で大まかなルート計画を行う航路 選択である。この戦略的航路選択では、大略の通 過点を決定するだけで、ノード及びリンクの安全 性については全く考慮されない。そこで、次段階 の戦術的航路選択で、操船者の危険度感覚を取り 入れ、さらに不要変針点除去などの整形フィルタ を通し、より実用的な出力が得られるようにした。

\section{2 画像処理}

一般的に、操船者がコースラインを設定する場 合、海図という 2 次元情報のみによる。コースラ インの設定の手順の中には、海図上の地形の高さ、 海域の水深、航路標識などの情報に加光、操船者 の知識や経験が考慮されていると考えられる。よ り好ましい結果を期待するなら、ここで扱う 2 次 元情報と 3 次元情報及び操船者の知識を結びつけ るためのサブシステムの構築が必要だが、種々の 制約のため今後の課題としたい。

海図などの印刷物から取り込んだ画像は、ノイ ズなどの除去を施した後、2 值画像化する。 2 值 画像の例を図 2 に示す。

ここで、 2 值画像を用いている理由として、

・バイナリイメージなので、データサイズ が比較的小さい

・簡単な空間フィルタを用いて地形の特徴の抽出が容易

などが挙げられる。

この 2 值画像の画素数は計算機の能力の許す限り多い方が良いが、本研究では都合上 $100 \times 100$ 画素とし た。より高速の計算機と多くの画素数が扱えれば、航路に兮長性を持たせることが容易となり、将来的に 任意点の航行環境を定量的に簡単に評価できるようになった場合により効果を発揮すると思われる。

\section{3 戦略的航路選択}

戦略的航路選択とは、画像処理によって得られた陸岸情報から、ノードの位置を設定し、Dijkstra法によ り大まかな経路を決定することである。Dijkstra法の手順 ${ }^{(2)}$ は、例えばノード数 $n$ からなるグラフがある場 合、まず、始点 $s$ に直接リンクがつながるノードのうち、もっとも短い距離のノードを見つけ、これにラ ベルを付すとともに経路を記憶する。次に、始点 $s$ またはラベルの付いたノードに直接リンクがつながり、 且つラベルの付してないノードのうち、始点 $s$ からの積算距離が最も短いノードにラベルを付すとともに、 このノードへの経路を記憶し、目的のノードまでの経路が得られるまで同様の手順を繰り返すことにより 最短路を見つけ出すことができる。なお、すべてのノードにラベルが付させるまで繰り返すと、始点 $s$ か ら他のすべてのノードへの最短路を見つけることができる。

戦略的航路選択の最初の情報となるノードの決定法として、

・岬などの特徵点を利用する方法

・島や陸岸の中心を利用する方法 
が考えられるが、前者については多くのノードが生じ、計算時間が非常に長くなるので後者を用いること とした。

Dijkstra法により戦略的航路を決定する場合、与えられたノード長とリンク長を考慮して最短となる経路 が解となる。しかし、実状ではノードの長さは必ずしも直線距離で表せなかったり、常に一定な值である とは限らない。任意の点の航行環境の定量的または定性的な評価が行うことができればより安全で効率的

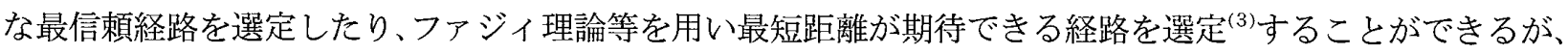
今回は直線的な距離をそのままノード間の距離とした。

一般的に、より安全な経路とは、「航路幅の広い水域を航過する」ことであると考えられるため、ノード の決定には初期画像をそのまま用いるのではなく、いったん「膨張、言い換えると地形情報を簡素化させ たものを利用することとした。これによって、より安全な経路の選択が期待できるためである。つまり、 膨張の度合いが大きいと航行可能な経路を見つけだすことはできないが、徐々にその度合いを下げてゆき 最初に見つかった経路が最も安全な経路と考えられるからである。例えば、図 3 (a) のように、膨張の度 合いが小さい場合または初期画像にそのままDijkstra法を適用すると、航路幅の狭い水道を選択してしまう が、膨張の度合いを大きくすることで図 3 （b）のように航路幅の広い経路を優先的に選択することができ る。

また、この膨張処理により、隣接する島のグルーピングをすることができ、不要なノードの生成を抑え ることができ、結果的に計算時間を短縮することができる。具体的な膨張の手法としては、

$$
\begin{gathered}
A \oplus B=\left\{c \in E^{N} \mid c=a+b \quad \exists: a, b \quad a \in A \text { かっ } b \in B\right\} \\
\text { ここに、 } \mathrm{A}: \text { 被演算画像 } \\
\mathrm{B}: \text { 演算画像 }
\end{gathered}
$$

として、任意の演算画像 B（Bの形状はできれば円形がより好ましい）を用いることが理想的だが、画素 数の関係上、簡略化して、

$$
\Sigma B_{i j} \geqq 1 \quad \text { ならば } B=1
$$

ここに、 $B_{i j}: A$ の座標 $(x, y)$ の画素から切り取ってできる $n \times n(n=1,3,5)$ の画像 $x, y=n \cdot k 、 n \cdot k+2 、 n \cdot k+3(k:$ 正の整数 $)$

を用いた。

このように膨張処理した初期画像から求めることができる任意の膨張処理された 2 島の面積中心 $C_{i}$ と $C_{j}$ と の間には必ず解放水域が存在することから、両中心の可航幅Wを、

$$
\begin{aligned}
W & =R_{i j}-\left(r_{i}+r_{j}\right) \\
& \text { ここ、 } R_{i j}: C_{i} \text { と } C_{j} \text { との距離 }
\end{aligned}
$$

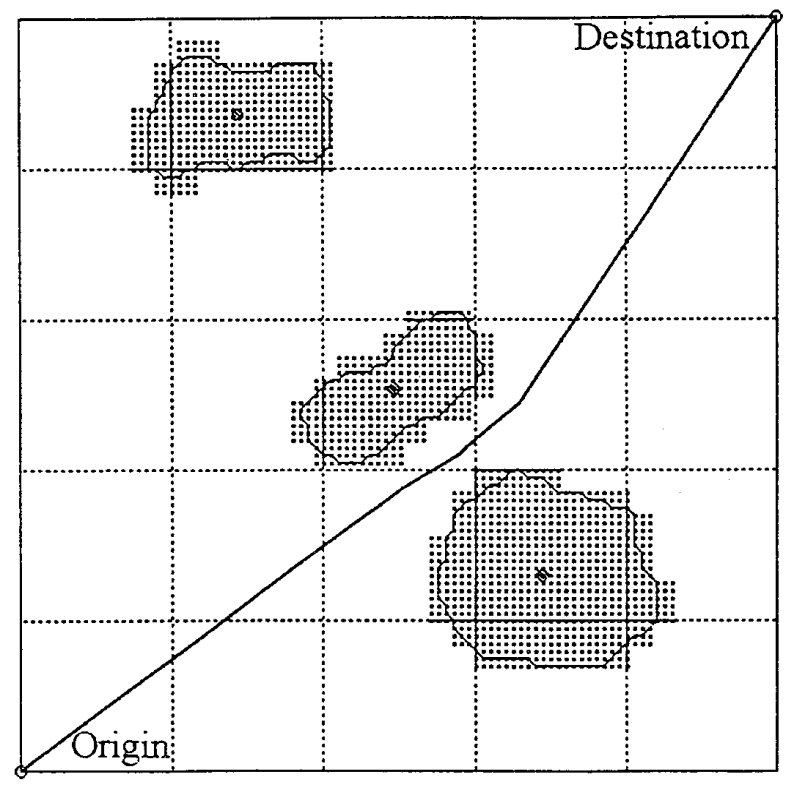

図 3 (a) 膨張の度合の小さい場合

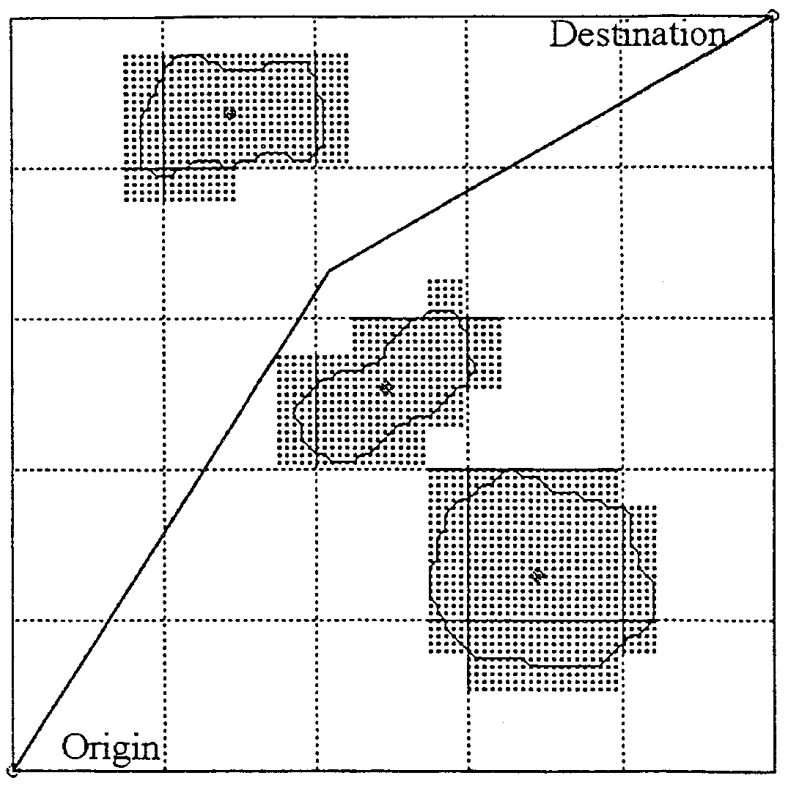

図 3 (b) 膨張の度合の大きい場合 


\section{$r_{i} 、 r_{j}:$ 島の面積と同等の円の半径}

とし、可航幅の中点にノードN $N_{i j}$ 設けた。このように、島の形状を考慮せずに、面積と同等の円の半径 $r$ のみの関係だけに依ると、島の形状が細長いような場合にノードによっては陸岸近傍になることもあるが、 ノードの数注島の数を $k$ とすると、ODの 2 点を含めるため、

$$
{ }_{k+2} C_{2}
$$

だけ生じる。

このように得られた任意の 2 ノード間には可航水域が必ず存在するが、計算時間の短縮のため、リンク 上に膨張処理された陸岸が存在しない場合にかぎりノードが連結しているものとした。図 2 に対する戦略 的航路選択を図 4 亿示す。

\section{4 戦術的航路選択}

戦略的航路選択では、大略のコースを設定するのみで、ノードやリンクの安全性については全く考慮さ れていない。そこで、戦術的航路選択で危険度レベルの設定を行うことができるようにした。この危険度 については 3 章で述べる。戦術的航路選択には、既存の操船避航モデルを利用することが考えられたが、 ここでは非常に簡易な手法として離岸距離が達成 したいレベル以下になった場合、付近の達成した いレベルを満たすような点を一次変換を用いて探 索する手法を用いた。

\section{5 整形フィルタ}

戦術的航路選択自体は危険度レベルを考慮した コースラインとなっているが、操船者の負担の軽 減のため不必要な变針点の削除、より航程の短い コースへの修正や变針角度を減少させるために整 形フィルタを通してより実用的なコースラインが 設定できるようにした。戦術的航路に整形フィル 夕を通した状況を図 5 に、また、最終的に自動設 定されたコースラインを図 6 に示す。

\section{3. 操船者の危険度感覚の知識ベースの作成}

\section{1 操船シミュレータ実験}

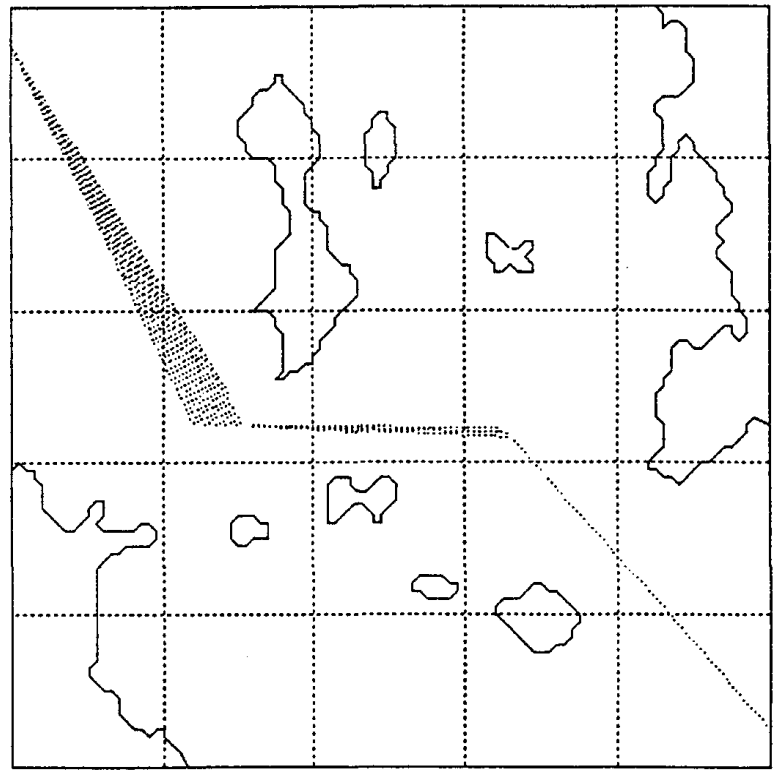

図 5 戦術的航路を整形フィルタに通した状況

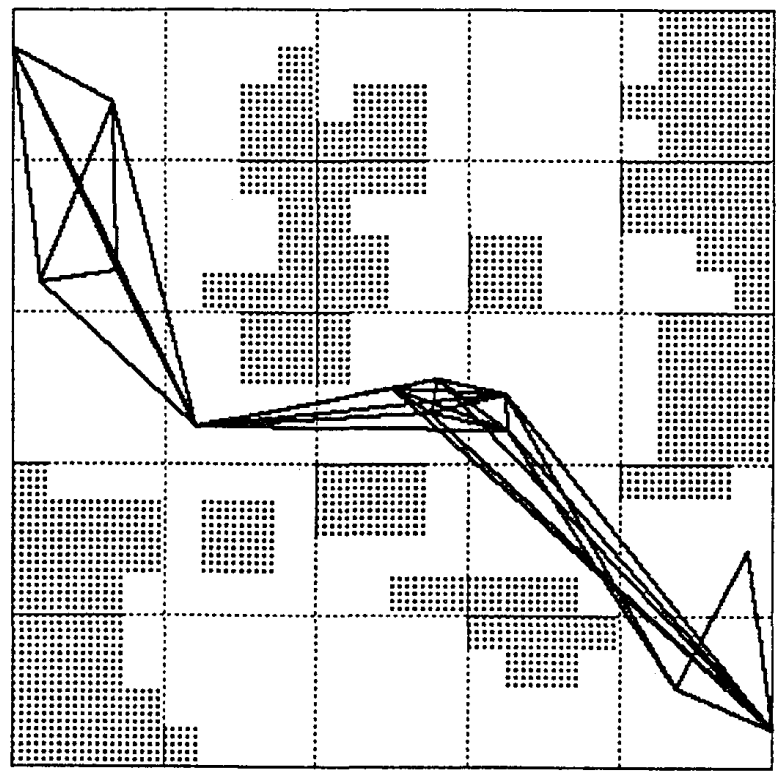

図4 戦略的航路選択の結果

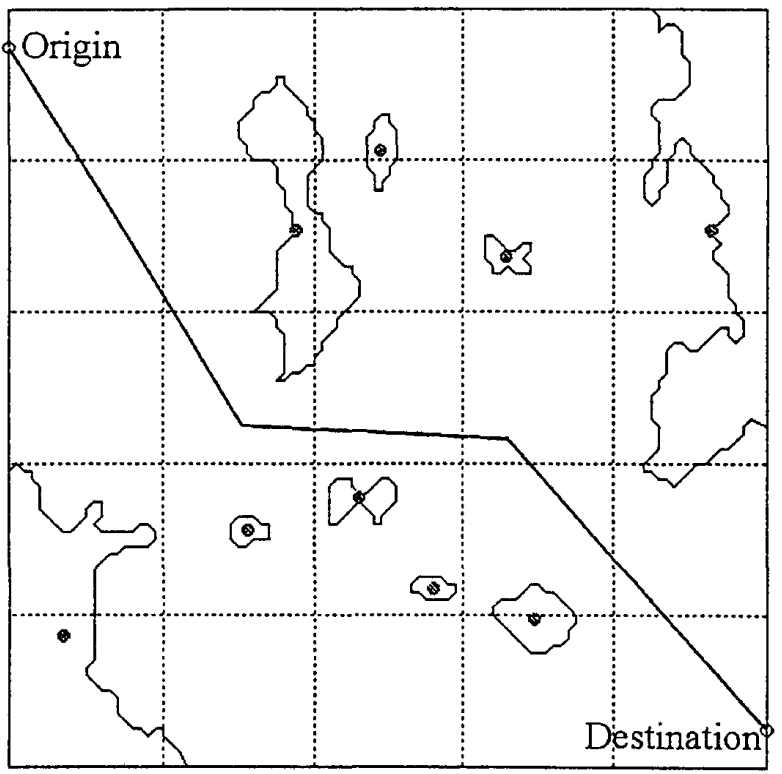

図 6 コースラインの自動選択結果 
コースラインの設定の過程で航行環境を指標化 する必要がある。航行環境の定量化のための項目 は四 7 に示すような階層構造(3)で表すことができる。 よって、総合的な航行環境の指標 $E$ は、操船者特 性指標 $E m$ 、船舶機能指標 $E_{s}$ 及び航行環境指標 $E_{e}$ で 表すと、

$$
E=f\left(E_{m}, E_{s}, E_{e}\right)
$$

となるが、各指標の要素すべてについて関係式を 求めたり、指標相互のウエイトを求めることは容 易ではない。今回は気象・海象の平穏な状態で、 航行環境指標 $E e$ の中の自然環境、とりわけ地形に よる操船者の危険度感覚がどのように表されるか 知ることが重要であると考え、四 8 のように操船 シミュレータを用いて総合的な地形に対する操船 者の主観的危険度 (以下 $S J_{L}$ と略す) を獲得するた めの基礎的な案験を行った。

実験は、操船シミュレータ上で全長、速力、陸 岸との交差角及び離隔距離を変化させ合計20ケー ス行った。被験者にはシミュレータ上の実験船が 陸岸に接近する状況で $S J_{L}$ が、

$$
\begin{aligned}
+3 & : \text { 非常に安全 } \\
+2 & : \text { 加り安全 } \\
+1 & : \text { や安全 } \\
0 & : \text { どちらともいえない } \\
-1 & : \text { やや危険 } \\
-2 & : \text { 加なり危険 } \\
-3 & : \text { 非常に危険 }
\end{aligned}
$$

の7段階でどのように感じるか評価を求めた。な 抒、実験船は 1 分ごとに停船させ主観的な評価の ための時間を設けた。

陸岸に対する主観的伦険度 $S J_{L}$ を、

$$
\begin{aligned}
S J_{L}=f(R / V, V, \theta, d) \\
こ こ に 、 \\
\mathrm{R}: \text { 陸岸までの離岸距離 }(\mathrm{m}) \\
\mathrm{V}: \text { 船速 }(\mathrm{m} / \mathrm{s}) \\
\mathrm{d}: \text { 離隔距離 (N.M.) } \\
\theta: \text { 陸岸との交差角 (deg.) }
\end{aligned}
$$

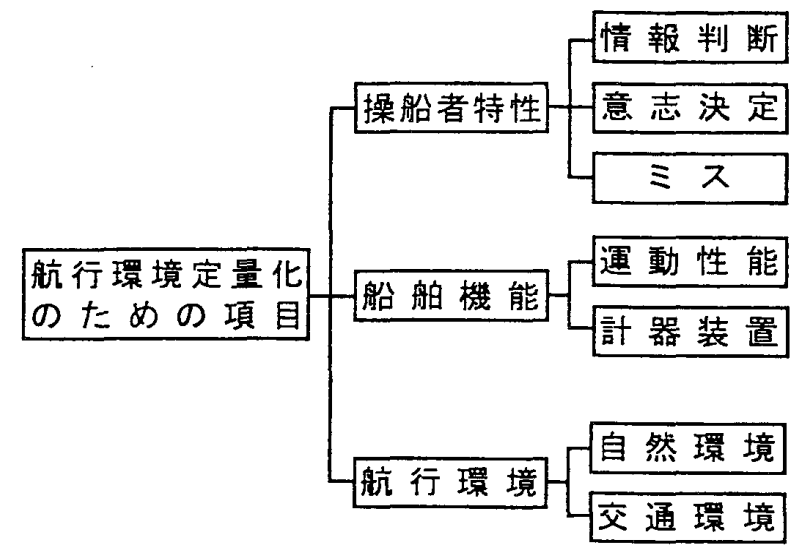

図 7 航行環境定量化のための項目

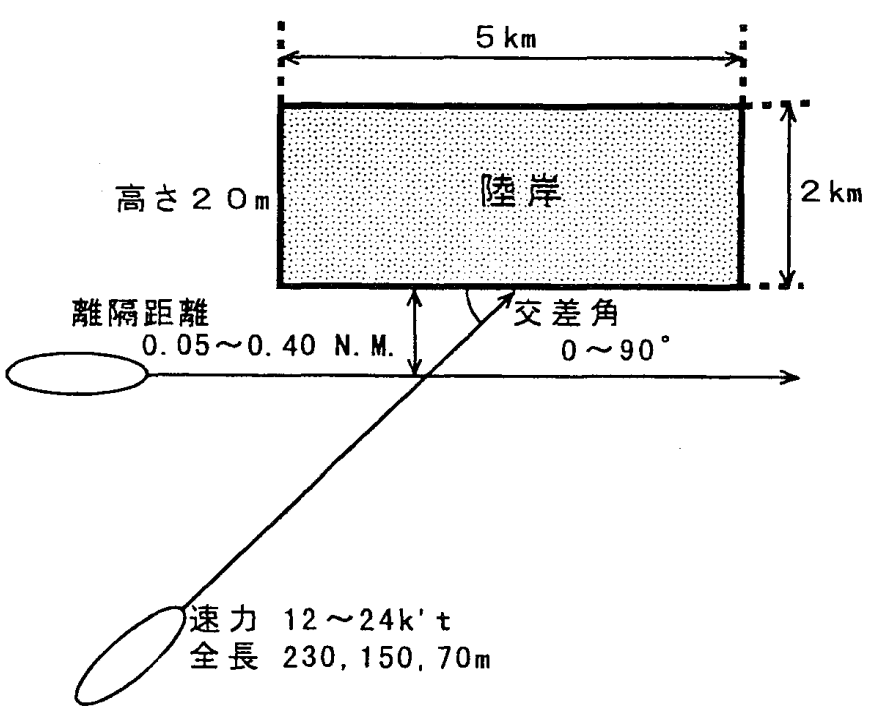

図 8 操船シミュレータによる実験概要図

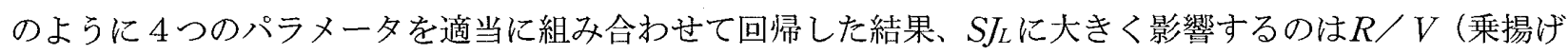
までの時間的余裕）とVであり、 $\theta$ についてはあまり影響がなく、最も簡単な形として、

$$
S J_{L}=f(R / V)
$$

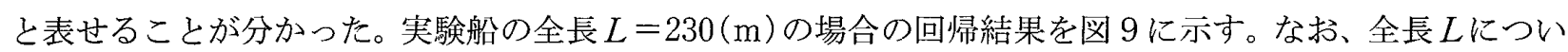
ては $230 \mathrm{~m} 、 150 \mathrm{~m}$ 及び70mの結果しか得られていないため、全長別に回州を行った。各全長に対し回帰式、

$$
\begin{array}{lll}
S J_{L}=0.010319 \cdot R / V-2.85451 & (L=70 \mathrm{~m}) & \text { (8) } \\
S J_{L}=0.009445 \cdot R / V-2.91328 & & (L=150 \mathrm{~m}) \\
S J_{L}=0.010519 \cdot R / V-3.26137 & (L=230 \mathrm{~m}) & \text { (10) }
\end{array}
$$

が得られた。

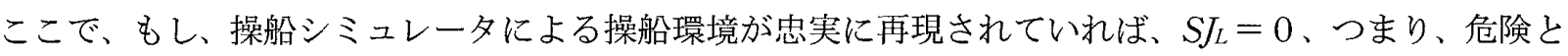
安全の判断の境目が操船判断のタイミングと密接に関係していると考えられる。一つの実験の流れの中で 


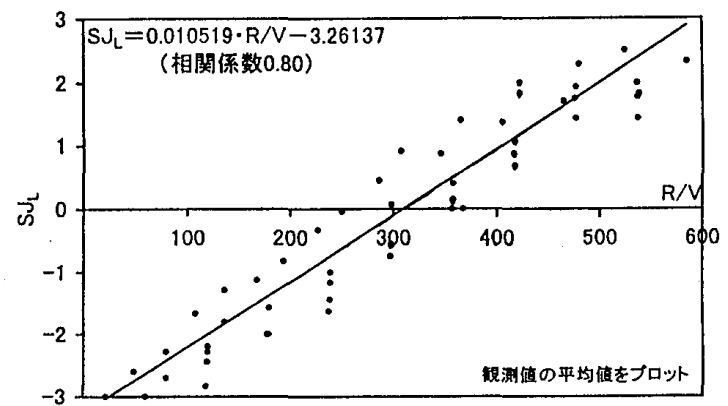

図 $9 L=230(\mathrm{~m}) の S J_{L}$ 回帰結果

初めて避航の必要性を感じる時期を全長比 $R / L$ で 集計すると図10に示す結果が得られた。同図から 離岸距離が $24 L$ 付近から避航の必要性を感じる安 全指向の被験者もいることがわかるが、概ね $216 L$ 付近加ら急激に増加し $8 L$ で最大の頻度をとって いる様子がわかる。平均值は $10.7 L$ といら結果が 得られた。このグラフは実験船が全長 $230 \mathrm{~m}$ のコン テナ船の場合で、一般的な最短停止距離 $10 L$ とよ く一致しているといえる。

一方、図11は陸岸まで時間的余裕がいくらにな ったら避航の必要性を感じるかを集計したもので ある。時間的余裕は平均 $256(\mathrm{~s}) 、 S J_{L}$ に換算する と約一 0.5 となった。

図10及び図11から、およそ次のことが言える。 つまり、操船者は、経験的な船舶の操縱特性の知 識から離岸距離と最短停止距離が一致する地点を おおおむ称 $S J_{L}=0$ と判断し、その時点で操船判断を 行い、その判断の実行の時間的遅れの結果または 状況の変化を見極めるための時間的な遅れの結果、 $S J_{L}=-0.5$ で避航すると回答していると考えられ る。このことから、操船シミュレータが概ね実際 の船橋の状態を模擬できており、さらに $S J_{L}$ が実状 に即した指標となっていると考えられる。

\section{2 実海域におけるコースライン}

$S J_{L}$ はコースラインの選定指標として用いること ができるが、実際に操船者がどの程度の危険度レ ベル (以下 $S J_{L}$ *と略す)、つまりどの程度の安全基

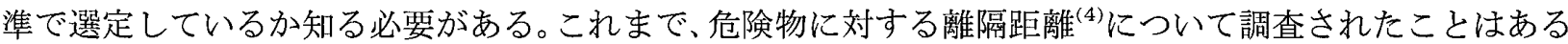
が、陸岸に対する離隔距離について詳しく調査されたものは見受けられず、地文航法関連の文献にも具体 的に船舶のとるべき離隔距離が明示してあることはほとんどなく、記述されている例として ${ }^{(5)}$ 、

内海航行

$$
1 / 2 \sim 1 \text { 海里 }
$$

外洋・沿岸航行

標識不備または測量粗悪な沿岸航行

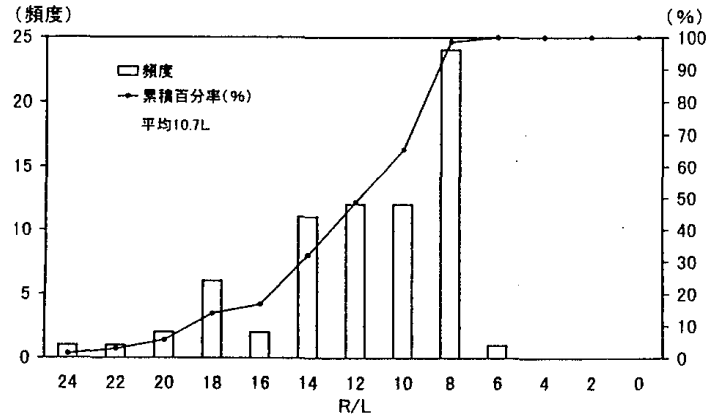

図10＼cjkstart初めて避航の必要性を感じる $R / L$

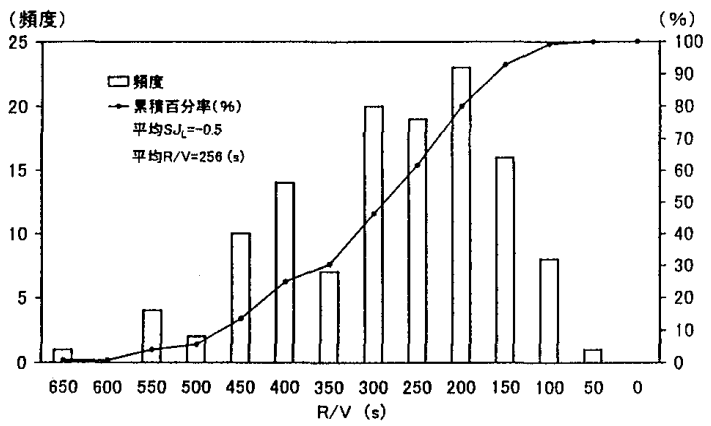

図11初めて避航の必要性を感じる $R / V$

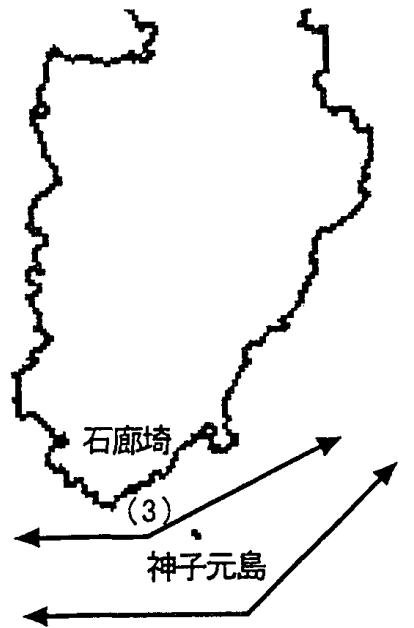

(4)

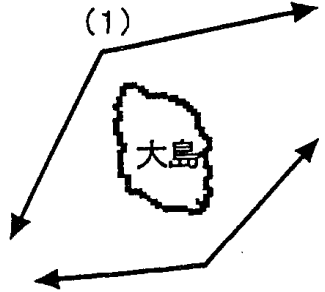

(2)

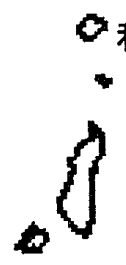

図12大島周辺海域の経路状況

と、曖昧な表現にとどめてある。これは自船の性能や航行環境により離隔距離は一概に言えないこともあ るが、これまで航行環境といら観点でほとんど検討がされていなかったものと思われる。

そこで、日本海難防止協会の実施した伊豆半島周辺の抽出海域における操船者の意識調査 ${ }^{(6)}$ のアンケート 結果から陸岸との離隔距離と船舶の全長の関係を求めることとした。

この海域では図12に示すように、大きく分けて 4 つのルートがある。このうち変針にODの影響があま 
りないと考えられる同図の(4)のような航路を回答 した船舶について神子元島との離隔距離を求める こととした。図13は総トン数 1 万トン以上の船舶 のコースライン設定状況である。ただし、この海 域で、大島北及び神子元島南方には日本船長協会 自主設定による分離通行方式が設定されており、 同意識調查で行われたアンケートで得たコースラ インの回答がよ゙の程度影響を受けているか詳細に ついては不明である。表 1 に示すように 1 万トン 以上の大型船については、東航の方が離隔距離が 大きくなっており自主設定による分離方式の影響 が見られるが、東航と西航を集計することで平均 像は求まるものと考光られる。集計の結果、神子 元島に対し離隔距離 $R$ と全長 $L$ の関係、

$$
R=0.0117 L+0.837 \quad \text { （相関係数 } 0.97 ）
$$

$$
\begin{gathered}
こ こ に 、 \\
R \text { : 離隔距離 (N.M.) } \\
L: \text { 全長 }(\mathrm{m})
\end{gathered}
$$

を得た。なお、陸岸との離隔距離 $R$ と船舶の全長 の関係について

は、船舶明細書 ${ }^{(7)}$ の特定の船種から得た回鹵式、

$\log V=0.369 \log L+0.433 \quad$ （相関係数 $0.77 ）$

(12)

$$
\text { ここに、 } \begin{array}{r}
V: \text { 速力 }\left(k^{\prime} t\right) \\
L: \text { 全長 }(\mathrm{m})
\end{array}
$$

を用いた。

\section{$3.3 S J_{L}$ と離隔距離の対応}

$S J_{L}$ と離隔距離の対応を示したのが図14である。 沿岸でのコースラインの選定は、S $S J_{L}$ が+3(非常 に安全）〜+2（かなり安全）に対応しているの がわかる。操船者は、運航スケジュールに基づき、 経済性、安全性などを評価し、最も効率的な航路 を設定していると考えられ、安全の面から、陸岸 を意識する必要がないように達成しようとする安 全レベル $S J_{L}{ }^{*}$ が+ $3 \sim+2$ となる離隔距離を確保 したコースラインを定めていると考光られる。このことからも、SJLをコースラインの安全性や船舶の航行 状態を評価する一つの指標として用いることができると考えられる。

\section{4、SJ $\boldsymbol{J}_{L}^{*}$ 考慮したコースラインの自動設定例}

戦術的航路選択に評価指標 $S J_{L}$ を組み込むとともに沿岸航行の評価基準である $S J_{L}{ }^{*}=+3$ をちると、図 15（a）及び図15（b）に示すような結果となった。この結果は図13に示した多くのコースラインの平均的 な結果が得られていることがわかる。なお、全長 $L=230(\mathrm{~m})$ 、速力 $V=20 （ \mathrm{k}$ 't $)$ とした。

本研究で用いた簡単なアルゴリズムを用い沿岸航行でのコースラインの自動設定の効果が期待できるが、 実際に必要とされるのはむしろ内海航行や狭水道航行時であろう。そこで、アルゴリズム自体には手を加 えず、来島海峡を南航する場合に適用した結果が図16である。一見して海上交通安全法上の航路に沿って コースラインが設定されているように見えるが、航法を考慮するアルゴリズムは含まれていない。この例 


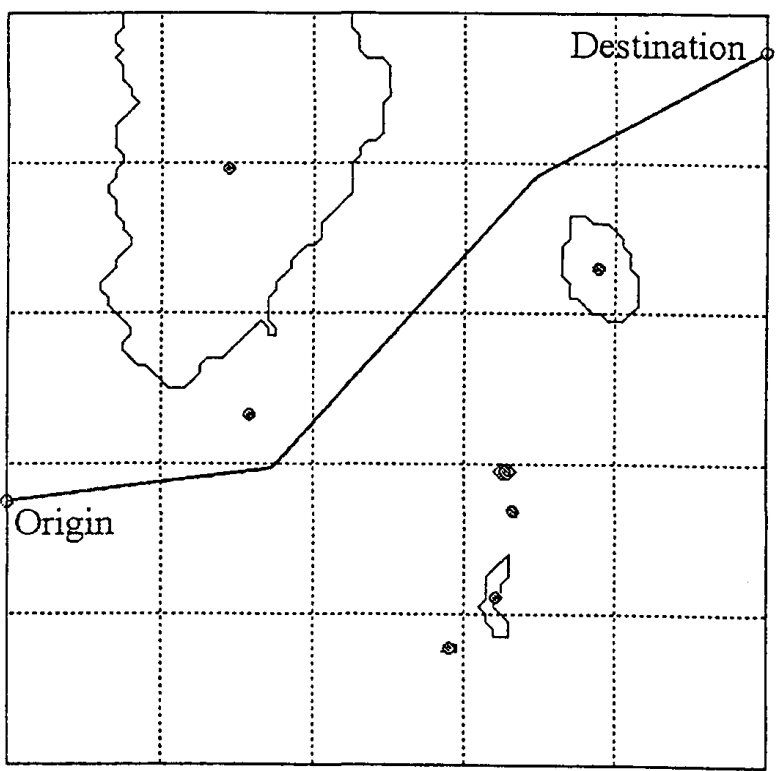

図15（a）大島北を航過する場合

のように、狭水道航過するためには $S J_{L}^{*}=-3$ と設 定しなければならず、SILがこのような狭水道航行 にそのまま流用できるかは若干検討を要すると考 えられる。

また、本研究のコースラインの自動設定には、 対象船舶の操縱性能が考慮されていない。沿岸域 では先に示した例のように実用に耐えうるコース ラインが設定できるが、狭水道を対象とした場合、 船舶の運動性能上コースラインに沿って航行でき ないことも考えられる。一般的に、次の变針点と の距離が新針路距離 $\mathrm{S}^{(9)}$ 、

$$
\begin{aligned}
& S=V\left(T+\frac{t_{1}}{2}+\frac{1}{K \cdot \delta_{0}}+\cdot \tan \frac{\theta}{2}\right) \\
& \text { ここに、 } \quad V: \text { 速力 }(\mathrm{m} / \mathrm{s}) \\
& T: \text { 追従性指数 }(\mathrm{s}) \\
& K: \text { 旋回性指数 }(1 / \mathrm{s}) \\
& \theta: \text { 変針角 }(\mathrm{deg} .) \\
& \delta_{0}: \text { : 舵角 }(\mathrm{deg} .) \\
& t_{1}: \text { 舵中央から舵角が } \delta_{0} \text { となるまでの時間 }(\mathrm{s})
\end{aligned}
$$

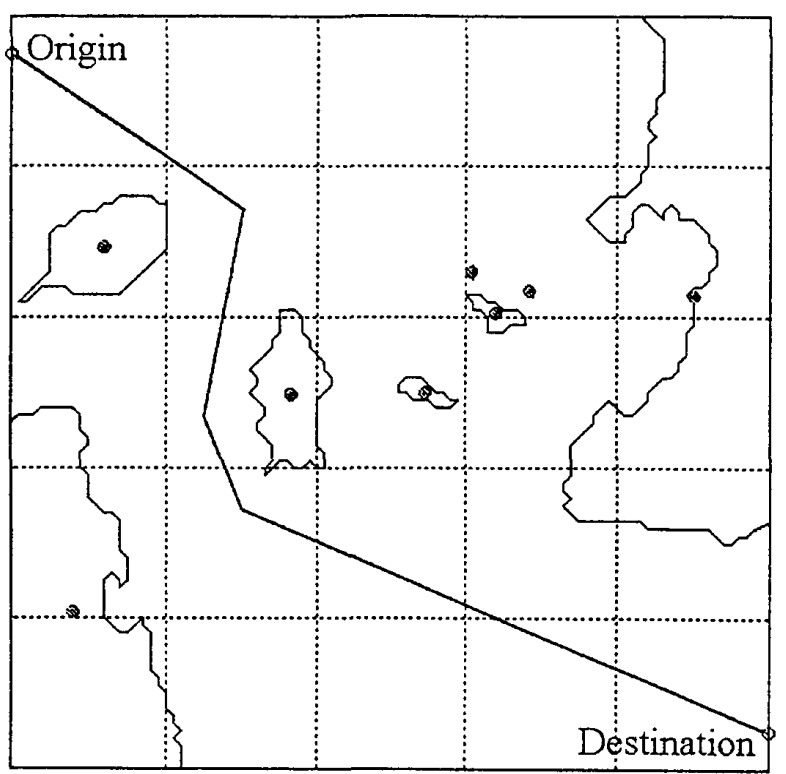

図16 来島海峡南航の例

以上である必要がある。これは、次の変針点との距離が $S$ 未満であれば、設定したコースラインに沿って 航行できないためである。

また、SJLはある瞬間での平均的危険度感覚を示しているため、コースラインを通じた操船者負担や操船 経験に応じた航行の可否、言い換えるとコースラインの指標についても考慮すべきである。このような操 縱性能の指標とコースラインの指標を合わせた評価手法については検討中である。

\section{5.おわりに}

本研究では、簡単な既存の手法を組み合わせたアルゴリズムで使用に耐えうるコースラインの自動設定 が行えることを示した。ただし、このような単純なアルゴリズムの問題点として、 
・対象海域に存在する島や陸岸が極端に少ない

・ODのいずれかが島影で、他の島を見通せない

場合には連結したノードが得られずコースラインが設定できないことがある。

今後の課題として以上の問題を解決するとともに、実際の海域は地形情報のみならず、潮流などの気象 ・海象や他船の影響などもっと広義の操船環境や交通環境の影響も考慮されるべきで、これらをごのよう に指標化するか検討する必要がある。また、設定した航路全体について定量的な評価をするための指標に ついて考察を要する。

\section{参 考 文 献}

（1）安井院猛・中島正之：画像工学の基礎，昭晃堂，1995年10月.

(2) 劉・王：ファジィネットワーク工学, 日本理工出版会，1995年10月.

（3）日本海難防止協会：航行環境の定量的評価手法に関する調查研究，p.49，1992年 3 月など.

（4）山田篤利・松本吉春・市瀬信夫・浜畑 勇：危険物等の離隔距離について，日本航海学会誌，1965年 12月。

(5) 長谷川健二：地文航法，p.352，海文堂，1985年.

（6）日本海難防止協会：沿岸海域における航行安全対策に関する調查研究，1996年 3 月.

（7）日本海運集会所：日本船舶明細書，1995年.

（8）本田啓之輔：操船通論，p.31，1988年.

\section{質 疑 応 答}

遠藤 真(富山商船高等専門学校)：コースライン自動設定の流れのスタートがなぜ陸岸物標の情報なので しょうか? 水深情報を取り入れればより適切な拘束条件となるのではと考えられます。むしろ、水深情 報で狭水道のコースは大略決定されると考光られます。

田中隆博：ご指摘のとおりアルゴリズム構筑の段階で最低でも水深情報については考慮すべきとの意見が ありました。水深情報については、

・対象海域の任意点について詳細な情報がある

・対象海域で概敉必要な離岸距離（等水深線など）の情報がある 場合が考えられます。前者については本研究で扱っているより情報レベルが高いと考えられますが、適 当なしきい值で 2 值化した水樑情報を地形情報に重ねることで、後者については、初期画像に 2.3 で示し た(1)または(2)式を用い、離岸距離分だけ劣化させることで対応可能と考えています。

また、自動設定の流れのスタートを陸岸物標の情報としたのは、現在のところ簡単に処理できないと の指摘を既に受けていますが、レーダからの地形情報を用い、自船が陸岸に乘り揚げることを避けるシ ステム、つまり、「居眠り海難の防止」などに寄与できればと考えたためです。

喜多秀行 (鳥取大学工学部)：戦略レベルの選択で想定しているルート々戦術レベルの選択で選ばれるルー 卜は必ずしも一致しないと思われますが、その整合性ついてはどのように㧍考えでしょうか。

田中隆博：ここで戦術的航路選択と呼んでいるものは、戦略的航路選択を基準として達成したい安全レ心゙ ル $S J_{L}$ *にならない部分については、付近で $S J_{L}$ *を満をす点に修正を行いますので、ODを直結できる場 合以外は一般的に両者が完全に一致することはありません。また、ルートについては、対象海域に解 $\left(S J_{L}{ }^{*}\right.$ を満たすようなルート）が存在すれば、例えば、戦術レベルで戦略レベルとは異なった隣接する水路を 通るといったように両者で経路に不一致を生じることはありません。ただし、ご指摘は、どの程度のレ ベル以内で両者の整合性が保たれているからこのように単純なアルゴリズムでも有効であるかといった ような評価の実施の有無についてと存じますが、今回は行っておりませんので今後の課題と致します。 